\title{
The Correlation Between Gadget and Learning Motivation Towards Insomnia Incident of the Nursing Students
}

\author{
$1^{\text {st }}$ Anny Rosiana Masithoh \\ Universitas Muhammadiyah Kudus \\ Kudus, Central Java, Indonesia \\ annyrosiana@umkudus.ac.id \\ $4^{\text {th }}$ Heni Siswanti \\ Universitas Muhammadiyah Kudus \\ Kudus, Center Java, Indonesia
}

\author{
$2^{\text {nd }}$ Nasriyah \\ Universitas Muhammadiyah Kudus \\ Kudus, Central Java, Indonesia \\ $5^{\text {th }}$ Nabilatur Rohmatul Faizah \\ Universitas Muhammadiyah Kudus \\ Kudus, Central Java, Indonesia
}

\author{
$3^{\text {rd }}$ Sukesih \\ Universitas Muhammadiyah Kudus \\ Kudus, Central Java, Indonesia
}

\begin{abstract}
The development of technologies increasingly rapid such as gadget. It has been widely used in society, especially among students. Many students use gadget unefectivel therefore it can decrease the interest in learning and the event of insomnia. Based on the results of preliminary study, the results of interviews with 10 students of first semester S1 Nursing are they used gadgets for more than 3 hours per day. In the morning when they have class until midnight, they still use gadget. They use gadget not only to learn but also to entertain. Moreover, they usually can sleep at midnight. This research aims to determine the correlation between the use of gadgets and the interest in learning with the insomnia in the first semester of S1 Nursing STIKES Muhammadiyah Kudus. This research belongs to Correlation Study with cross sectional research design. The population was 134 students and the sample was 57 respondents. The sampling technique was the Simple Random Sampling method and it used the Solvin formula. This research used questionnaire Spearman Rank test. Therefore, there is a significant correlation between the use of gadgets and interest to learn with $p$ value 0,001 and there is a significant correlation between the use of gadget and insomnia with $p$ value $=0,000$. It can be concluded that there is a correlation between the use of gadgets with interest in learning with insomnia in the first semester students of STIKES Muhammadiyah Kudus 2018.
\end{abstract} students

Keywords-Gadget, motivation, insomnia, nursing

\section{INTRODUCTION}

Education is the important pillar for nation building. The nation is considered advanced in terms of the level of higher education. The level of higher education is related to the quality of human resources. The quality of human resources becomes the main source in the nation's development because the quality of human resources is high so it will facilitate the development of the nation. If the quality of human resources is low, it will influence the national development. Improving the quality of human resources in the field of education has been carried out with various efforts. Efforts that have been made include, curriculum changes that increasingly require children to think more critically and provide adequate facilities and infrastructure (Shah, 2011).
Students will get maximum learning results if they are serious in their learning. Learning activities carried out both on campus and at home must be based on the desires that arise from within him. If child has a desire from within to learn then, the child will have an interest to learn, then he will try as much as possible to achieve the aims of learning activities. But there are many factors that make learning interest in students do not exist. One of them is the development of technology that increasingly developing (Dinar, 2010).

The interest of learning is influenced by the development of increasingly sophisticated gadgets. Many students abuse gadgets. Now we see teenagers and even children using gadgets for more than 3 hours. Therefore, the interest of learning decreased because of gadget. So they are increasingly lazy to open books, look for textbooks, and rarely read books. This is one of the case of their interest in learning decreases (Derry, 2011).

The development of technology and information is progressing very rapidly, which is marked by progress in the field of information and technology. Indonesia is one of the nations involved in the advancement of information and technology media. The technology developed, one of them is a gadget. Gadgets are used by all people including students in elementary school age to adulthood. The increasing use of gadgets or tools that are easily connected to the internet has increased from time to time. Currently approximately 45 million use the internet, and 9 million are using mobile phone (gadget) to access the internet. This number is increasing because it is more easily accessible and affordable prices from smart phones (Ameliola \& Nugraha, 2013).

Gadgets are sophisticated items created with various applications that can present a variety of news media, social networks, hobbies, and even entertainment. This sophisticated item in terms of price is not exactly cheap. It is not only used as entertainment media but also for business interests, or work on college and office assignments. In fact the gadget not only used by adults or the elderly (22 years and over), adolescents (12-21 years), but also children (7-11 years), and more ironically, gadgets are used for children (3-6 years), which should not 
be eligible to use gadgets. There are several factors using gadget, such as the child's decreased interest, also has impact on sleep patterns or insomnia (Widiawati, 2014).

In a survey conducted by the Central Statistics Agency (BPS) in collaboration with the Indonesian Internet Service Providers Association (APJJII), noted in Indonesia 2016 the internet users more than half of Indonesia's population found that 132.7 million Indonesians were connected to the internet. The total population of Indonesia is 256.2 million. This indicates an increase $51.8 \%$ compared to the number of internet users in 2014, the survey conducted by APJJII in 2014 and there are 88 million internet users.

Based on primary study, most of students use gadgets more than 3 hours per day. When they study, they also still use gadgets for social media, chatting with their peers and at night they still use the gadget until late at night. It also makes student interest in learning decreases because, when getting material in lecturing time, they play gadgets. Therefore, the researcher would like to know the correlation between the use of gadget and the interest in learning with insomnia for nursing students

\section{METHOD}

This research used Correlation Study, to know the correlation between two variables. The sampling technique is random sampling technique. There are 57 people as the sample in this research

\section{RESULT}

This research, there are several data that analyzed such as age, gander. the duration of using gadget, interest to learn and insomnia analysis.

First, based on the "age" analysis, the highest percentage 50,9\% come from 19 years old. The lowest is $3.5 \%, 17$ years old. The minimum age is 17 years old and maximum is 20 years old. Second, based on gander analysis, $73,3 \%$ are female, and $26,3 \%$ are male. Third, based on analysis of the duration using gadget, 84,2\% students use gadget more than 3 hours per day. Fourth, based on the analysis of interest to learn, there are 59,9\% students are categorized in the enough category, and $49,1 \%$ students are categorized into less category. Fifth, in the analysis of insomnia analysis, $47,4 \%$ students are categorized into "enough insomnia", 45,6 \% students are high insomnia and $7 \%$ students are in the minor category.

The analysis of the use of gadget and the interest to study can be seen in table 1 . Based on table 1 , the result of $\mathrm{p}$ value is $0,001<(\alpha=0.05)$. It means that $\mathrm{Ha}$ is accepted, and $\mathrm{Ho}$ is rejected. Therefore, it can be concluded that there is correlation between the use of gadget and the interest to learn in nursing students

TABLE 1. CORRELATION BETWEEN THE USE OF GADGET AND THE INTEREST TO STUDY (N=57)

\begin{tabular}{|c|c|c|c|c|c|c|c|c|}
\hline \multirow{3}{*}{$\begin{array}{c}\text { The Use of } \\
\text { Gadget }\end{array}$} & \multicolumn{4}{|c|}{ Interest to learn } & \multicolumn{2}{|c|}{ Total } & \multirow{2}{*}{$\begin{array}{r}\text { P } \\
\text { Value }\end{array}$} & \multirow{2}{*}{$\begin{array}{r}\mathrm{R} \\
\text { (rho) }\end{array}$} \\
\hline & \multicolumn{2}{|c|}{ Less } & \multicolumn{2}{|c|}{ Enough } & & & & \\
\hline & $\mathrm{N}$ & $\%$ & $\mathrm{~N}$ & $\%$ & $\mathrm{~N}$ & $\%$ & & \\
\hline$<3$ hours & 0 & 0.0 & 0 & 0.0 & 0 & 0.0 & 0.001 & 0.425 \\
\hline 3 hours & 0 & 0.0 & 9 & 100 & 9 & 100 & & \\
\hline$>3$ hours & 28 & 58.3 & 20 & 41.7 & 48 & 100 & & \\
\hline Total & 28 & 49.1 & 29 & 50.9 & 57 & 100 & & \\
\hline
\end{tabular}

value $0,000<(\alpha=0.05)$. Therefore, it can be concluded

To know the relation between the use of gadget and the insomnia can be seen in table 2. The results of statistical tests using the Spearman's Test rho obtained $\mathrm{p}$ that $\mathrm{Ha}$ is accepted and $\mathrm{Ho}$ is rejected if $\mathrm{p}$ value $<0.05$. There is a correlation between the use of gadgets and the insomnia in nursing students.

\begin{tabular}{cccc} 
TABLE 2. THE CORRELATION BETWEEN THE USE OF GADGET AND THE INSOMNIAOF NURSING STUDENTS TAHUN 2018 (N=57) \\
\hline The Use of Gadget & Incident of Insomnia & Total & $\mathrm{P}$
\end{tabular}

\begin{tabular}{|c|c|c|c|c|c|c|c|c|c|c|}
\hline \multirow[t]{3}{*}{ 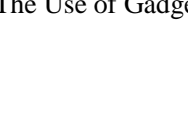 } & \multicolumn{6}{|c|}{ 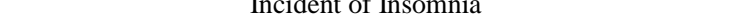 } & \multicolumn{2}{|c|}{ t } & \multirow{2}{*}{ Value } & \multirow{2}{*}{ (rho) } \\
\hline & \multicolumn{2}{|c|}{ Low } & \multicolumn{2}{|c|}{ Medium } & \multicolumn{2}{|c|}{ High } & & & & \\
\hline & $\mathrm{n}$ & $\%$ & $\mathrm{n}$ & $\%$ & $\mathrm{~N}$ & $\%$ & $\mathrm{n}$ & $\%$ & & \\
\hline$<3$ hours & 0 & 0.0 & 0 & 0.0 & 0 & 0.0 & 0 & 0.0 & 0.000 & 0.476 \\
\hline 3 hours & 3 & 33.3 & 6 & 66.7 & 0 & 0.0 & 9 & 100 & & \\
\hline$>3$ hours & 1 & 2.1 & 21 & 43.8 & 26 & 54.2 & 48 & 100 & & \\
\hline Total & 4 & 7.0 & 27 & 47.4 & 26 & 45.6 & 57 & 100 & & \\
\hline
\end{tabular}

Source: Primary data, 2018.

\section{DISCUSSION}

Based on the results of research on the use of gadgets conducted on 57 respondents, the result is $84,2 \%$ respondents use gadget more than 3 hours and only $15,8 \%$ respondents use gadget 3 hours.
In line with research according to Alhuda Sodiq (2017), this negative-value dependence can affect students including student interest in learning, health, sleep disorders (insomnia), behavior, etc. Students are now very spoiled with gadgets and all kinds of sophistication. Gadgets that should only be a companion tool in obtaining information more broadly are now 
turning functions into a way of life for students because of their sophistication that can reach the entire world.

In term of the interest to learn, $49.1 \%$ have unfavorable learning interest and $50.9 \%$ have good interest in learning. The loss of student interest in learning became a terrible scourge for the development of education. The success of education should be faced by all of people therefore it can increase the quality of human resources. But it looks very difficult because of gadget. To minimize these negative impacts of gadget, as users we must be more intelligent in using gadgets and using them wisely tailored to their needs.

Based on analysis in the incidence of insomnia there were $47.4 \%$ of respondents has "moderate insomnia" categorized, $45.6 \%$ has "high insomnia" categorized. The study found that the majority of insomnia were "moderate inmsonia". With the depth interview, the respondents had trouble in sleeping not because they were doing work but they play gadgets and often woke up at night. They also said that before going to sleep, they use gadget. And in the midnight, they also wake up only to use the gadget. Therefore, it makes them do not looked fresh in the morning.

Based on the analysis the correlation between use of gadget and the interest to study, the $p$ value is $0.001<(\alpha$ $=0.05$ ). It means that there is a significant correlation between the use of gadget and the interest to learn of nursing students in STIKES Muhammadiyah Kudus. The students often used gadgets such as social media and others in the class. This makes them ignore lecture material delivery by lecturers. In fact, many of them prefer to play gadgets rather than focus on learning activities. The delay in using this gadget has an impact on the loss of focus when the activity of teaching and learning takes place. This also has an impact on the appearance of laziness or a decrease in one's interest in learning.

Based on analysis the correlation between the use of gadget and the insomnia, the $\mathrm{p}$ value is $0.000<(\alpha=0.05)$. It means that there is a significant correlation between the use of gadget and the insomnia of nursing students of STIKES Muhammadiyah Kudus. One of the things that affects sleep disorders is dependence by gadgets. Increased waking every night (waking up several times) which certainly can lead to sleep problems. Moreover, the higher use of gadgets will result in decreased quality of sleep or insomnia. Insomnia that occurs in adolescents will have an impact on physical and psychological health. Especially those who are still at the educational stage, insomnia in adolescents can have an impact in terms of physical health, such as being easily sleepy during the day which can result in disruption of learning activities in class. Futhermore, insomnia also can decrease the concentration of learning which can have an impact on decreasing adolescent academic achievement. The inability of students in managing the time to use gadgets properly and correctly at home or on campus, will have an impact on irregular resting patterns and sleep patterns so that it can trigger insomnia. Therefore, the use of gadget more than 3 hours per day can disturb the sleep pattern and can cause insomnia.

\section{CONCLUSION}

Based on the analysis, it can be concluded that 1). $84,2 \%$ respondents use gadget more than 3 hours., 2) there are $50,9 \%$ respondents have "enough category" in the interest to learn, 3) there are $47,4 \%$ respondents have insomnia in "moderate category", 4) There is a correlation between the use of gadgets and the interest to learn, with $p$ value $(0.001)<(\alpha=0.05)$. Moreover, based on the correlation coefficient value 0.425 , it means that the correlation is positive (unidirectional). If the respondents are using gadgets> 3 hours per day, there is a risk of decreased interest in learning. 6) There is a correlation between the use of gadgets and the insomnia, with $\mathrm{p}$ value $(0,000)<(\alpha=0.05)$. The correlation coefficient value is 0.476 , it means that the correlation is positive (unidirectional). It can be concluded that tif the respondents are using gadgets $>3$ hours per day, there is a risk of severe insomnia.

\section{REFERENCES}

[1] Ameliola, S. d. (2013). Perkembangan Media Informasi dan Teknologi Terhadap Anak Dalam Era Globalisasi . Malang : Universitas Brawijaya.

[2] Arikunto. (2010). Prosedur Penelitian Suatu Pendekatan Praktek. Jakarta: Rineka Cipta.

[3] Aspuah, S. (2013). Kumpulan Kuesioner dan Instrumen Penelitian Kesehatan. Yogyakarta: Nuha Medika.

[4] Astin, N. (2013). Dampak Penggunaan Handphone Terhadap Minat Siswa. e-jurnal Dinas Pendidikan volume 5.

[5] Ayuningtyas, P. (2009). Studi Korelasi Antara Minat Belajar Dan Persepsi Terhadap Metode Mengajar Dengan Keterlibatan Belajar Mahasiswa Pada Posisi Duduk Di Belakang.

[6] Azwar. (2009). Metodologi Penelitian . Yogyakarta: Bum Aksara.

[7] Christianty, J. (2011). Hubungan Penggunaan Situs Jaringan Sosial Terhadap Perilaku Remaja di Kota Makasar. Jurnal Penelitian IPTEK-KOM Volume 13 Nomor 1, 1-23.

[8] Daryanto. (2009). Panduan Proses Pembelajaran Kreatif dan Inofatif. Jakarta: AV Publisher.

[9] Derry, I. (2011). Bila Si Kecil Bermain Gadget: Panduan Bagi Orangtua Untuk Memahami Faktor-Faktor Penyebab Anak Kecanduan Gadget. Google Book.

[10] Dinar, B. (2010, September 27). Minat Belajar. Retrieved from Informasiku.com: http://www.informasiku.com/2010/12/minatbelajar-untuk-meningkatkan.html

[10] Djaali, H. (2015). Psikologi Pendidikan . Jakarta: PT Bum Aksara.

[11] Elizabeth, H. (2013). Perkembangan Anak Jilid 2. Jakarta: Erlangga.

[12] Ferdina Rozalia, M. (2017). Hubungan Intensitas Pemanfaatan Gadget Dengan Minat Belajar Siswa Kelas 7 . e-jurnal Keperawatan volume 5 nomor 2 2527-3043.

[13] Hidayat, A. (2010). Riset Keperawatan dan Teknik Penulisan Ilmiah . Jakarta : Salemba Medika.

[14] Hidayat[, S. (2014). Kecanduan Penggunaan Gadget dengan Kejadian Insomnia Pada Mahasiswa RIK UI, e-jurnal Keperawatan.

[15] Kompas. (2016). Pengertian Siswa Menurut Para Ahli.

[16] Larasati, R. \&. (2012). Skripsi Program Studi Ilmu Keperawatan Universitas Indonesia Depo. Hubungan tingkat stres dengan kejadian sleep paralysis pada mahasiswa FIK UI ankatan 2008 , 40.

[17] Machfoedz. (2009). Metodologi Penelitian (Bidang Kesehatan, Keperawatan, Kebidanan, Kedokteran). Yogyakarta: Fitramay.

[18] Makmur, K. (2014). Psikologi Belajar. Yogyakarta: Aswaja Pressindo.

[19] Manumpil, D. (2012). Hubungan Penggunaan Gadget Dengan Tingkat Prestasi Siswa Di SMA Negeri 9 Manado. e-jurnal Keperawatan volume 3 nomor 2 april 2015. 
[20] Muhibbin, S. (2011). Psikologi Belajar. Jakarta: PT.Raja Grafindo Persada.

[21] Notoatmodjo. (2010). Metodologi Penelitian Kesehatan. Jakarta: PT.Reneka Cipta.

[22] Oktia Rohmah, C. (2016). Pengaruh Penggunaan Gadget Dan Lingkungan Terhadap Minat Belajar Siswa Kelas X Kompetensi Administrasi Perkantoran SMK Muhammadiyah 2 Yogyakarta.

[23] Potter, A. P. (2008). Buku Ajar Fundamental Keperawatan: Konsep dan Praktik Vol 2 Edisi 4. Jakarta: EGC.

[24] Risal, M. (2011, Agustus 24). Apa Itu Gadget dan Pengertian Gadget. Retrieved from artikelind.com: http://www.Artikelind.com/2011/apa-itu-gadget-dan-pengertiangadget/

[25] Riwidikdo, H. (2012). Statistika Kesehatan. Yogyakarta: Nuha Medika.

[26] Sanjaya, R. d. (2011). Menyiasati Tren Digitas Pada Anak Menggunakan Teknologi Informatika. Jakarta: PT Elex Media Komputindo.

[27] Semiun, Y. (2012). Gangguan Mental 2. Yogyakarta: KANISIUS.

[28] Setiawan, S. d. (2010). Metodologi Penelitian Kebidanan DIII, DIV, S1 dan S2. Yogyakarta: Nuha Medika.

[29] Slameto. (2010). Belajar Dan Faktor-Faktor Yang Mempengaruhi. Jakarta: Rineka Cipta.

[30] Statistika, B. P. (2016). Penggunaan Internet Di Indonesia.

[31] Sugiyono. (2010). Metodologi Penelitian. Bandung: Alfabeta.

[32] Susanto, A. (2016). Teori Belajar Pembelajaran. Jakarta: PRENADAMEDIA GRUP.

[33] Susilo, Y. \&. (2011). Cara Jitu Mengatasi Insomnia (sulit tidur). Yogyakarta: C.V ANDI OFFSET

[34] Walgito, B. (2011). Pengantar Psikologi Umum. Yogyakarta: CV Andi Offset.

[35] Widiawati, d. (2014). Pengaruh Penggunaan Gadget Terhadap Daya Kembang Anak. Jakarta: Universitas Budi Luhur. 